\title{
AKTUALISASI DISTANCE LEARNING PADA MASA PANDEMI COVID-19 DI JENJANG PENDIDIKAN DASAR DAN MENENGAH
}

\author{
Nuryana $^{1,}$ Mia Fatimatul Munsi ${ }^{2}$ \\ IAIN Syekh Nurjati Cirebon \\ nuryana@syekhnurjati.ac.id; miafatimatul@syekhnurjati.ac.id
}

\begin{abstract}
ABSTRAK
Penelitian ini bertujuan memaparkan aktualisasi distance learning pada masa pandemi, respons guru dan siswa terhadap distance learning, serta faktor-faktor pendukung dan penghambatnya. Adapun metode penelitian yang digunakan adalah studi literatur. Dari berbagai sumber literatur tersebut, dapat disimpulkan bahwa guru dan siswa secara umum sudah memahami alasan dan melaksanakan distance learning. Namun, guru dan siswa menemukan berbagai kendala yang mengakibatkan siswa secara umum lebih senang belajar tatap muka secara langsung daripada distance learning. Distance learning yang dilaksanakan di jenjang pendidikan dasar dan menengah menyampaikan materi dengan beragam cara, misalnya; membaca, merangkum, membuat video, dan lain-lain. Media pembelajaran yang digunakan bervariasi, misalnya; Whatsapp, Google Classroom, Google Form, Zoom, Cisco Webex, Quiziz, Edmodo, Eduboy, Youtube dan lain-lain. Dalam segi penilaiannya dapat digunakan berbagai asesmen yang sesuai dengan karakteristik distance learning (Misalnya, tes berbasis daring, portofolio, atau penilaian diri (self assessment)). Dalam pembelajaran distance learning ini ditemukan faktor-faktor pendukung dan juga penghambat. Faktor pendukung antara lain pemerintah, guru, dan fasilitas pembelajaran itu sendiri. Misalnya faktor teknologi, pemberian kuota gratis, perluasan akses internet, penyediaan fasilitas belajar seperi Rumah Belajar dan Belajar dari Rumah di TVRI. Sedangkan faktor penghambat tersebut diantaranya siswa tidak memiliki laptop atau ponsel pintar, tidak memiliki jaringan internet yang baik, siswa tidak memahami penggunaan media pembelajaran yang digunakan guru, dan lain-lain.
\end{abstract}

Kata Kunci: Distance learning, pandemic_covid-19, Pendidikan Dasar dan Menengah.

\section{ABSTRACT}

This study aims to describe the actualization of distance learning during the pandemic, the responses of teachers and students as well as the supporting and inhibiting factors of distance learning. The research used literature study method. From various sources of literature, it can be concluded that teachers and students in general have understood the reasons and have implemented distance learning. However, teachers and students encountered various obstacles such the students prefer face-to-face learning rather than distance learning. Distance learning which is carried out at the primary and secondary education levels delivers material in various ways, for example; reading, summarizing, making videos, and so on. The learning media used are varied, for example; Whatsapp, Google Classroom, Google Form, Zoom, Cisco Webex, Quiziz, Edmodo, Eduboy, Youtube and others. In terms of assessment, various assessments can be used in accordance with the characteristics of distance learning (for example, online-based tests, portfolios, or selfassessments). This research found supporting factors and obstacles in distance learning. The supporting factors include the government, teachers, and the learning facilities themselves. For example, the technology factor, the provision of free data plan, expansion of internet access, the provision of learning facilities such as Rumah Belajar and Belajar dari Rumah

Jurnal Edueksos Vol. X, No. 1, Juni 2021 
on TVRI. While the inhibiting factors of distance learning include students do not have laptops, smart phones, and a good internet network, besides, students do not undertand the use of learning media used by teachers, and others.

Key Words: Distance learning, pandemic Covid-19, Primary and Secondary Education.

\section{A. PENDAHULUAN}

Isu pandemi Covid 19 hingga hari ini masih menjadi catatan dan perhatian penting bagi semua pihak. Pandemi menarik untuk dicermati bukan saja karena telah menjadi problem nasional dan internasional, tetapi juga dampaknya yang hingga saat ini masih terus dirasakan, bahkan semakin mengarah pada ketidakpastian yang sulit untuk diprediksi kapan pandemi akan berakhir. Terhitung sejak pertengahan Maret 2020 hingga saat ini, hampir satu tahun Pandemi Covid 19 telah melanda seluruh negara di berbagai belahan dunia termasuk Indonesia. Akibat pandemi telah banyak merubah tatanan kehidupan mulai dari sosial, kesehatan, ekonomi, kesejahteraan, tingkat pengangguran, perindustrian, keamanan dan lain-lain hingga di bidang pendidikan. Hal tersebut senada dengan pernyataan Anugrahana (2020) bahwa Pandemi covid-19 telah mengubah kebijakan berbagai bidang baik bidang pendidikan, pemerintah pusat maupun pemerintah daerah.

Dalam bidang pendidikan, persoalan pandemi covid 19 telah memberi dampak yang cukup signifikan. Dengan tingginya potensi penularan Covid-19 telah menjadikan pendidikan harus segera menyesuaikan tata kelola agar pelaksanaan pendidikan tidak membahayakan bagi para penyelenggara atau subjek dan objek pendidikan. Itulah sebabnya melalui Surat Edaran Nomor 4 Tahun 2020 tentang pelaksanaan kebijakan pendidikan dalam masa darurat penyebaran Coronavirus Diesiease (Covid-19), KEMENDIKBUD RI menegaskan bahwa:'Berkenaan dengan penyebaran Coronavirus Disease (Covid19) yang semakin meningkat maka kesehatan lahir dan batin siswa, guru, kepala sekolah, dan seluruh warga sekolah menjadi pertimbangan utama dalam pelaksanaan kebijakan pendidikan" (Pusdiklat Pegawai Kemendikbud RI: 2020). Oleh karena itu, Kemendikbud menetapkan bahwa proses belajar dari rumah dilaksanakan dengan melalui pembelajaran daring atau jarak jauh yang 
dilaksanakan untuk memberikan pengalaman belajar yang bermakna bagi siswa tanpa terbebani tuntutan menuntaskan seluruh capaian kurikulum untuk kenaikan kelas maupun kelulusan.

Dalam surat edaran tersebut secara ekplisit menjelaskan bahwa pelaksanaan pembelajaran pada semua lembaga pendidikan di masa pandemi Covid 19 harus dilakukan dengan jarak jauh (distance learning). Mulai dari persoalan administrasi hingga praktek pembelajaran diarahkan agar dilakukan dengan jarak jauh. Konsekuensi dari penyelenggaraan pembelajaran dengan jarak jauh itu secara otomatis mendorong para prakatisi pendidikan untuk menggunakan sistem penegloalaan dan pengajaran secara daring atau dalam jaringan (online). Suka atau tidak suka semuanya dipaksa harus siap untuk melakukan pembelajaran secara daring. Peraturan tersebut berlaku untuk semua jenjang pendidikan mulai dari pendidikan dasar maupun menengah baik formal maupun non formal.

Pendidikan dasar sebagaimana tertuang dalam Undang-undang Sistem Pendidikan Nasional RI No. 20 Tahun 2003, terutama pasal 17 adalah berbentuk Sekolah Dasar (SD) dan Madrasah Ibtidaiyah (MI) atau bentuk lain yang sederajat serta Sekolah Menengah Pertama (SMP) dan Madrasah Tsanawiyah (MTs) atau bentuk lain yang sederajat. Sedangkan Pendidikan menengah sebagaimana dalam pasal 18 UUSPN No. 20 Tahun 2003 merupakan lanjutan pendidikan dasar yang terdiri atas pendidikan menengah umum dan kejuruan. Pendidikan menengah berbentuk Sekolah Menengah Atas (SMA), Madrasah Aliyah (MA), Sekolah Menengah Kejuruan (SMK) dan Madrasah Aliyah Kejuruan (MAK) atau bentuk lain yang sederajat (Dirjen Pendididkan Islam, Depag RI, 2006:14).

Pendidikan dasar dan menengah sebagai bagian dari embrio bagi lahirnya generasi bangsa yang cerdas dan berkualitas dituntut untuk terus melakukan upaya pendidikan secara terprogram dan berkesinambungan. Pendidikan bagi anak mutlak diperlukan sejak dini dalam rangka mengantisipasi berbagai persoalan yang mungkin dan akan terjadi di masa depan (Suyanto dan Hisyam, 2010:53). Meskipun demikian, Komisi Perlindungan Anak Indonesia (KPAI) mengisyaratkan kurang setuju jika pendidikan anak baik pada jenjang pendidikan 
dasar ataupun menengah dilakukan secara langsung atau tatap muka, mengingat situasi pandemi yang terjadi sampai hari ini disinyalir masing belum kunjung berakhir. KPAI menyarankan agar pemerintah dapat memperkuat kebutuhan pada proses pembelajaran daring (Nugroho, 2020:1).

Dalam realitas dunia pendidikan masa kini sejatinya memang kerap memanfaatkan sistem digital. Dunia digital dapat dikatakan bukanlah sesuatu yang baru, karena dapat dipastikan bahwa penggunaan alat elektronik berupa alat komunikasi handphone misalnya seakan telah manjadi bagian dari aktivitas keseharain yang tak terpisahkan, termasuk penggunaan laptop di dalamnya. Para praktisi pendidikan dalam hal ini guru dan siswa dapat dikatakan telah mengenal dengan baik apa itu handphone dan laptop sebagai alat komunikasi. Sebegitu mengenal para siswa dan guru dengan alat komunikasi berupa handphone dan laptop sepertinya tidak menjadikan masalah ketika pembelajaran harus dilakukan melalui daring, terlebih dari waktu ke waktu di mana fitur dan aplikasi yang tersedia dalam alat komunikasi berupa handphone dan laptop terus mengalami perubahan dan peningkatan, bahkan dapat dikatakan semakin canggih. Seperti yang dikatakan oleh Siti dalam Padli \& Rusdi (2020) bahwa daya jangkau proses belajar mengajar jaringan komputer tidak terbatas oleh ruang dan waktu.

Oleh karena itu, apa yang menjadi tuntutan distance learning pada era Covid19 yang mana pembelajaran harus dilakukan secara daring tampaknya memungkinkan untuk bisa diaktualisasikan. Seruan pemerintah tentang pembelajaran agar dilaksanakan dengan jarak jauh adalah sinergis dengan ketersediaan media pembelajaran berupa alat elektronik handphone dan laptop yang ada saat ini sebagai media pembelajaran. Kata 'media' berasal dari Bahasa Latin, medius yang seacara harfiah berarti "tengah", "perantara”, atau 'pengantar". Media merupakan salah satu komponen komunikasi, yaitu sebagai pembawa pesan dari komunikator menuju komunikan Criticos (dalam Fauzi, 2014). Sedangkan Gagne dan Briggs dalam Arsyad (2014) menyebutkan "media pembelajaran meliputi alat-alat secara fisik digunakan untuk menyampaikan isi materi pengajaran, yang terdiri dari buku, tape recorder, kaset, video kamera, 
video recorder, film, slide (gambar bingkai), foto, gambar, grafik, televisi, dan komputer". Dari kedua pendapat tersebut dapat disimpulkan bahwa media pembelajaran merupakan salah satu komponen pembelajaran yang berperan sebagai perantara antara siswa dan guru dalam proses pembelajaran. Adapun yang dapat dijadikan media adalah semua yang ada di sekitar yang dapat bermanfaat bagi pembelajara, seperti buku, power point, slaide, foto/ gambar, video, televisi, dan lain-lain.

Sementara itu, Distance Learning dapat diartikan sebagai Pembelajaran jarak Jauh. McKenna dalam (Unger \& Meiran, 2020) mengatakan “distance learning implementation may have reduced socialization or communication between students when compared to a traditional classroom”. Pendapat tersebut dapat dipahami bahwa implementasi pembelajaran jarak jauh akan mengurangi sosialisasi atau komunikasi antarsiswa jika dibandingkan dengan ruang kelas tradisional. Meskipun begitu, pembelajaran jarak jauh menjadi pilihan yang dianjurkan disaat pandemi covid-19 semakin merebak. Senada dengan hal tersebut, Rizal (dalam Ahmad, 2020) mengatakan "pembelajaran jarak jauh adalah proses pembelajaran yang dilakukan tidak dalam bentuk tatap muka langsung antara pendidik dan peserta didik. Keduanya tidak berada di tempat yang sama pada saat pembelajaran berlangsung. Komunikasi antara guru dan siswa berlangsung dua arah yang dijembatani oleh penggunaan media, seperti komputer, televisi, radio, telepon, internet, video, dan sebagainya.

Sebagaimana beberapa pendapat di atas, dapat dipahami bahwa distance learning berarti pembelajaran jarak jauh yang tidak melibatkan siswa atau guru berkomunikasi dan bersosialisasi secara langsung atau tatap muka. Pembelajaran dilakukan secara daring (dalam jaringan). Pada masa pandemi covid-19, pembelajaran jarak jauh sangat dianjurkan oleh pemerintah guna menekan penyebaran virus covid-19, terutama di kalangan warga sekolah baik pada jenjang pendidikan dasar maupun pendidikan menengah.

Berdasarkan latar belakang yang telah dipaparkan, maka permasalahan penelitian ini mengarah pada bagaimana aktualisasi distance learning pada 
jenjang pendidikan dasar dan menengah, respons guru dan siswa terhadap distance learning, dan faktor apa saja yang mendukung dan menghambat dalam distance learning. Persoalan inilah yang perlu ditinjau sehingga dapat diketahui seberapa jauh efektivitas distance learning di lapangan. Bahkan untuk mendukung ketercapaian proses pembalajaran dengan jarak jauh tersebut, sehingga apa yang menjadi kendala dalam pengimepelentasiannya dapat segera dicarikan solusi dan pemecahannya.

\section{B. METODE PENELITIAN}

Penelitian ini menggunakan pendekatan kualitatif dengan metode penelitiannya, yakni studi literatur. Studi literatur digunakan dengan tujuan untuk menelaah data rekam peristiwa (Bungin dalam Hanifah Salsabila et al., 2020), terutama data-data yang terkait dengan pelaksanaan pendidikan jarak jauh (distance learning) di sekolah-sekolah baik jenjang pendidikan dasar maupun menengah, respon siswa dan guru terhadap distance learning serta faktor-faktor yang mendukung dan menghambat pelaksanaan distance learning. Data dan informasi dikumpulkan dari sumber buku, artikel ilmiah baik dari jurnal nasional maupun internasional. Setelah data dikumpulkan, selanjutnya dianalisis dan disimpulkan sesuai dengan permasalahan penelitian.

\section{HASIL DAN PEMBAHASAN}

Hasil penelitian ditemukan beberapa hal penting terkait aktualisasi distance learning, respons guru dan siswa, serta faktor pendukung dan penghambat pelaksanaan distance learning pada jenjang pendidikan dasar dan menengah. Temuan-temuan tersebut akan dipaparkan sebagai berikut.

\section{Aktualisasi Distance Learning pada Pendidikan Dasar dan Menengah}

Menurut Arsyad (2013:45), belajar adalah suatu proses kompleks yang terjadi pada diri setiap orang sepanjang hidupnya. Sedangkan menurut (Dimyati dan Mudjiono:2013:17), belajar merupakan tindakan dan perilaku siswa yang kompleks. Sebagai tindakan, maka belajar hanya dialami oleh siswa sendiri. Siswa adalah penentu terjadinya atau tidak terjadinya proses belajar. Proses belajar terjadi berkat siswa memperoleh sesuatu yang ada di lingkungan 
sekitar. Lingkungan yang dipelajari oleh siswa berupa keadaan alam, bendabenda, hewan, tumbuh-tumbuhan, manusia, atau hal-hal yang dijadikan bahan belajar.

Bahan belajar atau sumber belajar itu sendiri dapat dipahami sebagai "perangkat, bahan (materi), peralatan, pengaturan, dan orang di mana pembelajar dapat berinteraksi dengannya yang bertujuan untuk memfasilitasi belajar dan memperbaiki kinerja" (Januszewski dan Molenda dalam Arsyad: 2014). Berkenaan dengan hal tersebut, pembelajaran jarak jauh mendorong guru untuk memilih metode dan media pembelajaran yang tepat dan sesuai. Tepat berarti tujuan pembelajaran yang dimaksud dapat tercapai dan sesuai berarti cocok dengan situasi kondisi siswa maupun lingkungan belajarnya. Oleh karena itu, metode mengajar dan media pembelajaran merupakan hal yang sangat penting dalam menunjang pembelajaran. Unsur-unsur ini sangat berkaitan karena penentuan metode mengajar akan mempengaruhi media pembelajaran yang digunakan meskipun masih banyak hal yang harus diperhatikan dalam memilih media seperti tujuan pembelajaran, materi pembelajaran, dan karakteristik siswa (Sudjana, 2013:41).

Berdasarkan uraian di atas dapat disimpulkan bahwa konsep distance learning merujuk pada pembelajaran jarak jauh atau tanpa tatap muka secara langsung. Pertemuan yang dilakukan guru dengan siswa yaitu secara virtual melalui berbagai aplikasi pembelajaran digital yang digunakan. Berbagai aplikasi yang digunakan pada pembelajaran jarak jauh dipertimbangkan sesuai dengan tujuan dan kebutuhan pembelajaran. Pelaksnaan distance learning tidak terlepas dari proses pembelajaran yang tidak biasa bagi siswa. Mereka terbiasa dengan pembelajaran secara tatap muka dan mengandalkan guru sebagai fasilitator pembelajaran. Berbeda dengan masa pandemi sekarang, mereka dituntut belajar mandiri. Oleh karena itu, guru harus benar-benar merancang pembelajaran yang akan dilakukan dengan matang dan tepat agar tujuan pembelajaran tetap tercapai dan menyenangkan. Hal tersebut sesuai dengan pendapat Jamarah dan Aswan Zain (2014:53) yang menyatakan bahwa "proses 
pembelajaran merupakan suatu aktivitas yang perlu dirancang secara baik dan benar agar dapat mempengaruhi siswa dalam mencapai tujuan pendidikan yang telah ditetapkan".

Seperti yang telah disebutkan pada paragraf di atas, bahwa pembelajaran masa pandemi ini tidak hanya mengutamakan ketercapaian tujuan pembelajaran, namun juga menyenangkan. Dengan demikian, siswa tidak akan merasa terbebani jika belajar secara jarak jauh (distance learning). Dengan rancangan pembelajaran yang matang dan instruksi yang jelas dari guru, maka proses pembelajaran dapat berlangsung sesuai harapan. Berkaitan dengan itu, peran media pembelajaran tidak dapat dipandang sebelah mata. Media pembelajaran akan membantu menentukan keberhasilan pembelajaran jika digunakan secara optimal dan tepat sasaran.

Selanjutnya, pemanfaatan media seharusnya merupakan bagian yang harus mendapat perhatian guru dalam setiap kegiatan pembelajaran. Oleh karena itu, guru perlu mempelajari cara menetapkan media pembelajaran agar ia dapat mengefektifkan pencapaian tujuan pembelajaran dalam proses pembelajaran (Sudjana dan Rivai: 2013:31).

Dalam hasil penelitiannya di Jenjang Sekolah Dasar Kabupaten Subang, Roni Hamdani \& Priatna (2020) menyatakan bahwa tingkat efektivitas pembelajaran dari 8 indikator yang diteliti yaitu sekitar 66,97\%. Indikatorindikator tersebut mencakup 1) Kenyamanan Pembelajaran Masa Pandemi; 2) Kemampuan Literasi Digital Guru; 3) Tingkat Adaptasi Siswa terhadap Pembelajaran; 4) Kecukupan Perangkat; 5) Koneksi Internet; 6) Biaya Pembelajaran Daring; 7) Tingkat Kenyamanan Aplikasi; dan 8) Komitmen Daring Pasca Pandemi.

Bila dilihat dari tingkat efektifitasnya sebagaimana hasil penelitian Hamdani dan Priatna di atas mengisyaratkan masih belum optimalnya pelaksanaan pembelajaran daring pada pendidikan dasar. Hal tersebut selaras dengan hasil penelitian Abidin et al., (2020) tentang Efektifitas pembelajaran jarak jauh pada masa pandemi Covied-19 di SMP dan SMA Poltangan Pejaten 
Timur bahwa proses pembelajaran yang dilakukan dengan daring berjalan cukup efektif. Artinya bahwa apa yang menjadi target optimal dalam proses pembelajaran daring masih harus terus ditingkatkan. Menurutnya di sana sini masih terdapat beberapa hal hambatan yang mengganggu pembelajaran jarak jauh seperti masalah interaksi sosial guru dengan siswa dan ekonomi peserta didik yang nyaris belum siap.

Berkaitan dengan pembelajaran di jenjang Pendidikan Dasar, Simanjuntak \& Kismartini, (2020) juga menunjukkan dalam hasil penelitiannya bahwa pelaksanaan pembelajaran jarak jauh relative cukup baik, artinya bahwa pembelajaran masih dapat dikatakan belum berjalan secara maksimal sebagaimana yang diharapkan. Adapun dilihat dari proses cara mengajarnya dapat dijelaskan bahwa memberikan materi kepada para murid dilakukan oleh guru sebanyak 42, 86\% dengan kegiatan membaca kemudian merangkum materi, sebanyak 14,29\% guru melaksanakan pembelajaran dengan menggunakan berbagai aplikasi yang menunjang kreativitas, sebanyak 14,29\% guru melaksanakan pembelajaran dengan menumbuhkan karakter dan kreativitasnya, sebanyak 14,29\% guru melaksanakan pembelajaran dengan membuat video tutorial praktikan, dan sebanyak 14,29\% guru melaksanakan pembelajaran dengan memberikan materi melalui Whatsapp.

Dari beberapa uraian tersebut dapat disimpulkan bahwa aktualisasi distance learning pada jenjang pendidikan dasar melalui daring telah berjalan cukup baik. Hal tersebut dilakukan dengan proses pemberian materi yang bervariasi, misalnya dengan kegiatan membaca, merangkum materi. Demikian pula guru menggunakan aplikasi pembelajaran (Whatsapp atau aplikasi lainnya), atau membuat video tutorial praktikan.

Sungguh pun demikian, dengan memanfaatkan aplikasi-aplikasi pembelajaran, guru semakin kreatif dan inovatif. Hal tersebut sejalan dengan pendapat A. S. Lestari \& Gunawan (2020) yang mengatakan bahwa sistem pembelajaran daring dengan memanfaatkan platform digital pada jenjang sekolah dasar dan menengah cenderung mengubah wajah pendidikan ke arah 
yang lebih baik, lebih efektif, dan lebih menyenangkan. Guru pun menjadi semakin inovatif dalam mengemas bahan ajar dan semakin kreatif mengembangkan metode pembelajaran untuk menarik antusiasme siswa".

Hampir sama dengan pelaksanaan pembelajaran di jenjang pendidikan dasar, pembelajaran jarak jauh yang dilaksanakan di jenjang SMA/SMK juga tidak terlepas dari berbagai media pembelajaran yang digunakan. Berdasarkan hasil penelitian Sutia \& Sagita, (2020) satu orang guru dapat menggunakan lebih dari tiga media pembelajaran. Di antara beberapa media pembelajaran yang dapat digunakan guru antara lain Whatsap. Media Whatsapp relatif menjadi pilihan utama bagi para guru. Selain itu juga para guru dalam aktualisasi pembelajaran jarak jauh menggunakan media Google Classroom, Google Form, Zoom, Cisco Webex, Quiziz, Edmodo, Eduboy, dan Youtube dan Podcast (Sudarmoyo, 2020).

Sependapat dengan Sutia dan Sagita, menurut hasil penelitian W. Lestari (2021) juga menunjukan bahwa Whatsapp dianggap oleh para guru sebagai media pembelajaran yang paling mudah digunakan. Melalui Whatsap dapat digunakan berbagai fitur seperti foto, video, dokumen, Grup Whatsapp, dan panggilan (call) secara langsung. Selain itu, Whatsapp juga dikatakan mudah karena digunakan oleh berbagai kalangan, baik orang tua, remaja, bahkan anak-anak ada yang sudah difasilitasi Whatsapp oleh orang tuanya. Menurut Naserly (2020) bahwa Grup Whatsapp dapat mewakili setiap kelas yang berfungsi sebagai media untuk mengirimkan penjelasan tambahan melalui rekaman audio, sehingga materi yang diunggah di Google Classroom dapat tersampaikan secara lisan. Sejalan dengan itu, Elisvi et al., (2020) mengatakan bahwa whatsapp memberikan dampak positif terhadap siswa dalam memperoleh pengetahuan, berdiskusi, dan belajar secara aktif berinteraksi dengan mudah. Whatsapp bermanfaat dalam mengembangkan dan menggabungkan metode pembelajaran yang lain. Jadi, whatsapp akan lebih efektif jika dikolaborasikan dengan aplikasi lain. 
Aktualisasi distance learning pada masa pandemi ini bukan sekadar penyampaian materi dari guru kepada murid. Akan tetapi, pembelajaran yang memiliki umpan balik terhadap murid dan guru. Salah satunya adalah asesmen atau penilaian. Asesmen merupakan salah satu umpan balik untuk meningkatkan hasil pembelajaran. Asesmen merupakan suatu proses dan pengolahan informasi untuk mengukur pencapaian hasil belajar peserta didik (Ahmad, 2020). Menurut hasil penelitian Ahmad (2020) yang berjudul Alternative Assessment In Distance Learning In Emergencies Spread Of Coronavirus Disease (Covid-19) In Indonesia, model asesmen yang dapat diterapkan dalam Pembelajaran Jarak Jauh yaitu tes berbasis daring, portofolio, atau penilaian diri (self assessment). Model asesmen tersebut dapat dipilih guru sesuai dengan karakteristik materi dan tujuan pembelajaran.

\section{Respons Guru dan Siswa terhadap Distance Learning}

Respon dalam bahasan ini adalah suatu tanggapan, reaksi atau jawaban yang disampaikan oleh guru dan siswa terkait dengan distance learning (Artmanda, 2015:956). Respon dimaksud berkait dengan bagaimana tanggapan guru dan siswa terhadap pembelajaran jarak jauh di masa pandemi Covid-19 baik sebagai suatu kebijakan maupun pelaksanaannya di lapangan.

Secara real di lapangan, begitu beragam tanggapan guru dan siswa terhadap pembelajaran jarak jauh di masa pandemi. Sebagaimana penuturan (Simanjuntak \& Kismartini, 2020) dalam hasil penelitiannya menunjukan bahwa $45,81 \%$ siswa merasa senang dengan proses belajar di rumah dan 54, $19 \%$ siswa merasa kurang senang dengan proses belajar di rumah. Alasan siswa merasa senang dengan proses belajar di rumah, karena belajar dapat dilakukan dengan santai. Sedangkan siswa yang merasa tidak senang belajar di rumah, karena merasa jenuh tidak dapat bertemu dengan guru dan teman-teman sekolahnya.

Hal tersebut sejalan dengan hasil poling dan wawancara yang dilakukan oleh Lembaga Penjaminan Mutu Pendidikan (LPMP) DKI terhadap siswa SMA di Jakarta tertanggal 26 Mei 2020, yang menyatakan bahwa siswa 
menanggapi pembelajaran jarak jauh secara positif dan negative. Secara positif siswa menyatakan bahwa dengan pembelajaran jarak jauh (distance learning) memungkinkan dapat belajar dengan waktu yang fleksibel, menambah wawasan dan kemampuan dalam menggunakan berbagai aplikasi dalam proses pembelajaran. Demikian pula semakin menambah kedekatan dengan keluarga. Sedangkan negatifnya siswa merasa ribet belajar dengan serba online dan juga batas pengumpulan tugas yang terlalu cepat, sehingga menyulitkan bagi para siswa untuk bisa belajar dengan prestasi yang optimal.

Mencermati uraian di atas kiranya dapat dipahami bahwa pembelajaran jarak jauh (distance learning) bagi siswa ditanggapi sebagai sesuatu yang bukan sederhana. Pembelajaran jarak jauh memiliki dampak dan konsekwensi baik secara fisik masupun psikhis bagi siswanya. Bahkan sinyalemen tersebut dipertegas pula dengan pernyataan Arifin (2020) dalam hasil penelitiannya tentang respon siswa terhadap pembelajaran dalam jaringan masa pandemi Covid-19 di Madrasah Aliyah Al Amin Denpasar bahwa siswa merasa kurang menyenangkan terhadap pendidikan jarak jauh dengan sebab keterbatasan kuota, error aplikasi, kurang bimbingan guru, tidak bisa berdiskusi langsung dengan teman, sulit menerima materi dan terlalu banyak materi yang diberikan.

Dalam situasi pandemi memang tidak dapat dihindari bahwa pendidikan jarak jauh (distance learning) menjadi suatu pilihan. Sebab, pembelajaran yang dapat dilakukan dengan aman di situasi krisis pandemi seperti sekarang ini hanyalah dengan belajar jarak jauh melalui dalam jaringan (Online). Meskipun demikian, pembelajaran dengan jarak jauh tidak serta merta mudah dilakukan baik oleh siswa maupun gurunya itu sendiri.

Para guru dikatakan telah merespon dengan baik terhadap kebijakan distance learning ketika telah melaksanakan proses pembelajaran dengan jarak jauh melalui dalam jaringan (daring). Sebagaimana penuturan Sutia dan Sagita (2020) bahwa seluruh guru dinilai telah memahami apa yang menjadi alasan dan tujuan dari pembelajaran jarak jauh. Hampir dapat dipastikan bahwa semua 
sekolah baik pada jenjang pendidikan dasar maupun menengah seluruhnya telah melaksanakan pembelajaran daring.

Bagi guru mengajar adalah suatu kewajiban sehingga dalam situasi dan kondisi apapun proses pembelajaran dalam rangka mengajar dan mendidik siswa tetap harus dijalankan. Guru memahami bahwa masa pandemi adalah masa krisis di mana semua orang akan mudah tertular jika tidak memperhatikan protokol kesehatan. Oleh karena itu mengajar dengan jarak jauh dalam jaringan dipandang sebagai suatu keniscayaan. Suka atau tidak suka dan siap atau tidak siap guru dituntut untuk bisa merespon secara positif terhadap pelaksanaan pembelajaran jarak jauh (distance learning).

Sri Yunita, dkk (2020) menyatakan dalam hasil penelitiannya tentang respon guru terhadap kebijakan pembelajaran jarah jauh selama pandemic Covid-19 bahwa seluruhnya (100\%) guru menyatakan telah melaksanakan proses pembelajaran jarak jauh. Di sini terlihat bahwa respon guru termasuk baik terhadap kebijakan pembelajaran jarak jauh. Meskipun memang secara praktik bagaimana di lapangan masih perlu dicermati, mengingat siswa masih banyak yang merasa berat, bosan, sulit, jenuh dan lain sebagainya dalam pelaksanaan pembelajaran daring. Kesiapan dan kemampuan guru dalam proses pembelajaran daring harus terus ditingkatkan dalam berbagai halnya, agar pembelajaran jarak jauh melalui dalam jaringan berjalan efektif dan efisien.

Dalam pembelajaran jarak jauh peran guru tetap sangat menentukan keberhasilan pembelajaran. Sebagai perancang proses pembelajaran, guru dianjurkan dapat memilih dan menggunakan media pembelajaran yang sesuai dan praktis digunakan siswa. Jangan sampai memaksakan penggunaan media tertentu, tetapi siswa tidak dapat mengikutinya secara keseluruhan. Misalnya siswa merasa keberatan karena guru terlalu sering menggunakan aplikasi pembelajaran yang memakan banyak kuota internet yang akhirnya menekan pada faktor ekonomi keluarganya. 
Berkenaan dengan pembelajaran daring, seorang guru pun dapat berkoordinasi dengan guru lain baik masalah waktu pembelajaran daring (agar tidak berbenturan jam pelajaran), media pembelajaran yang digunakan, dan lain-lain. Hal tersebut agar pembelajaran satu dengan lainnya saling mendukung dan menunjang. Selain itu, dalam pembelajaran jarak jauh, guru bukan berarti cukup memberikan tugas kepada siswa tanpa memeriksanya. Akan tetapi, tugas-tugas yang diberikan harus guru periksa dan diberikan kembali kepada siswa sebagai perhatian dan catatatn bagi siswa.

Berdasarkan paparan di atas dapat dipahami bahwa guru dan siswa pada umumnya sudah memahami alasan pembelajaran distance learning. Itu sebabnya proses belajar-mengajar pada jenjang pendidikan dasar dan menengah secara umum dilaksanakan secara distance learning. Meskipun kemudian, hal tersebut menimbulkan berbagai kendala pada siswa. Oleh karena itu, respons siswa dan guru pada jenjang pendidikan dasar dan menengah pada dasarnya dapat diketahui bahwa mereka lebih cenderung pada belajar dan pembelajaran secara langsung (tatap muka).

\section{Faktor Pendukung dan Penghambat Distance Learning}

Terkait dengan aktualisasi pembelajaran jarak jauh (distance learning) di lapangan sudah barang tentu tidak terlepas dari faktor-faktor yang mempengaruhinya baik faktor yang sifatnya mendukung maupun menghambat. Secara naratif faktor-faktor tersebut dapat dipaparkan sebagaimana berikut.

Pertama Faktor Pendukung, dalam pembelajaran jarak jauh factor-faktor yang mendukung terhadap efektitas pembelajaran paling tidak sangat tergantung pada bagaimana komponen-komponen pembelajaran yang mengitarinya. Komponen-komponen dimaksud meliputi siswa, guru, bahan ajar, metode, sarana atau media, sistem administrasi dan evaluasi (Arikunto, 2014:5). Pembelajaran akan berjalan dengan efektif dan efisien apabila komponen-komponen tersebut saling mendukung dan melengkapi, demikian sebaliknya. 
Dalam konteks pembelajaran jarak jauh paling tidak faktor kesiapan guru, siswa, media, materi dan pendukung lainnya menjadi hal yang menentukan. Sebagaimana disampaikan dimuka bahwa dengan kemajuan ilmu pengetahuan dan teknologi saat ini di mana ketersedian alat-alat elektronik seperti laptop, Handphone, televisi, radio disertai dengan kelengkapan fitur dan aplikasi di dalamnya sangat mendukung untuk bisa dilakukannya interaksi dan komunikasi jarak jauh. Dengan demikian, secara prinsipiel sangat mungkin dan mendukung bagi terlaksananya pendidikan jarak jauh (Distance learning).

Sebagaimana penuturan Arizona et al., (2020) bahwa saat ini banyak aplikasi pembelajaran online yang bisa diterapkan dalam dunia pendidikan. Beberapa aplikasi gratis dan familiar yang dapat diterapkan antara lain; Whatsapp, Google Classroom, Google Form, Zoom, Cisco Webex, Quiziz, Edmodo, Eduboy, dan Youtube. Guru, tutor dan pengajar pada umumnya dapat membuka kelas dan mengundang peserta didik dalam kelas tersebut. Selain itu, masih banyak lagi platform maupun media online yang bisa diakses melalui jaringan internet oleh pengajar maupun peserta didik.

Bahkan Andrianto Pangondian et al., (2019) menambahkan dengan kehadiran teknologi berupa internet, ponsel pintar, dan laptop, maka secara otomatis akan sangat mendukung bagi terlaksananya pembelajaran jarak jauh dengan berbasis pada komputer yakni Computer Based Learning (CBL) maupun Computer Assisted Learning (CAL). Meskipun demikian, semua daya dukung tersebut akan berjalan efektif dan efisien dalam impelemntasinya apabila didukung dengan kesiapan guru dan siswa yang memadai pula.

Selanjutnya, selain faktor kemajuan dan ketersediaan teknologi di bidang IT, tak kalah pentingnya juga faktor dukungan pemerintah dengan memberikan kuota internet gratis kepada para guru dan murid, perluasan fasilitas internet di beberapa tempat, ketersediaan fasilitas belajar seperti Rumah Belajar, acara Belajar dari Rumah di TVRI semuanya merupakan factor yang mendukung bagi terwujudnya pembelajaran jarak jauh yang efektif dan efisien (Azzahra, 2020). 
Dengan demikian, aktualisasi pembelajaran distance learning pada masa pandemi ini sudah dilaksanakan hampir 100\%. Meskipun memang masih ada saja yang sebagian tidak melaksanakan distance learning dengan berbagai alasan keterbatasan. Pembelajaran dilakukan dengan cara home visit, yaitu guru mengajar dengan cara berkunjung ke rumah siswa. Hal tersebut dilakukan terutama bagi para siswa yang betul-betul tidak bisa menggunakan HP atau tidak memiliki HP.

Kedua faktor penghambat, dalam pelaksanaan pembelajaran jarak jauh (distance learning) pada pendidikan dasar dan menengah, hal-hal yang menjadi penghambat terlihat juga pada kesiapan guru, siswa, media dan aspek-aspek penunjang lainnya. Sebagaimana pendapat Fikri, dkk. (2021) dalam hasil penelitiannya bahwa hambatan yang dihadapi oleh guru dan siswa antara lain; terbatasnya layanan pembelajaran yang diberikan, kurangnya pemahaman penggunaan aplikasi pembelajaran, dan keterbatasan internet. Hal demikian sangat penting menjadi perhatian untuk kesiapan dalam pembelajaran online.

Hambatan tersebut tampaknya selaras dengan hasil penelitian Karim (2020) yang menyimpulkan bahwa sistem pembelajaran daring berbasis digital yang diandalkan masih memiliki kelemahan berupa akses jaringan yang belum memadai. Hal tersebut membuktikan bahwa pembelajaran belum sepenuhnya berjalan dengan baik. Arizona (2020) juga menambahkan bahwa selain masih adanya siswa yang belum memiliki laptop, komputer dan handphone, ternyata keterbatasan kuota internet dan masih belum familiarnya tenaga pendidik beserta peserta didik dalam mengaplikasikannya menjadi masalah tersendiri bagi kelancaran pembelajaran jarak jauh. Keberadaan penunjang berupa laptop, komputer, handphone dan kuota yang memadai menjadi penting terutama untuk membantu dalam mengerjakan tugas-tugas dari guru, seperti mengetik, membuat video, mengirim email, mengedit foto, merekam, atau hal lainnya. Hal tersebut dipertegas oleh hasil penelitian Kisworo \& Sumarni (2020) menyebutkan dalam pembelajaran online terkadang ada kendala baik di jaringan internet maupun pemahaman siswa. 
Berdasarkan paparan di atas, faktor pendukung dan penghambat menjadi hal yang sangat penting guna mengukur keberhasilan pembelajaran di masa pandemi covid-19 ini. Baik guru maupun siswa harus bersama-sama memahami kekurangan dan kelebihan belajar di masa pandemi. Faktor penghambat dapat dikatakan sebagai kekurangan dalam pembelajaran. Oleh karena itu, guru dapat mempertimbangkan dan memilah media pembelajaran yang cocok dengan karakteristik pelajaran dan karakteristik siswanya. Jika siswa kesulitan memiliki kuota internet, maka guru menggunakan media pembelajaran/ aplikasi yang ramah kuota (tidak menghabiskan kuota banyak). Contoh aplikasi yang ramah kuota salah satunya adalah whatsapp. Seperti yang dinyatakan oleh Alifarose Syahda Zahra (2020) bahwa aplikasi yang efisien menghemat kuota adalah whatsapp dan discord. Jadi, antara pemerintah, guru, siswa, dan orang tua harus saling bersinergi dan mendukung pembelajaran di masa pandemi demi tercapainya keberhasilan pembelajaran.

\section{KESIMPULAN}

Pembelajaran pada jenjang pendidikan dasar dan menengah umumnya sudah dilaksanakan secara distance learning (daring). Meskipun, ada juga beberapa sekolah yang melaksanakan pembelajaran dengan guru berkunjungn ke rumah (home visit). Guru dan siswa pun pada umumnya sudah memahami alasan pembelajaran distance learning tersebut. Aktualisasi distance learning dilaksanakan dengan berbagai cara penyampaian materi dan penggunaan aplikasi/ platform. Penyampaian materi dengan membaca, merangkum, membuat video, dan lain-lain. Sementara itu, aplikasi dan platform yang digunakan guru pada pembelajaran jarak jauh yaitu penggunaan Whatsapp, Google Classroom, Google Form, Zoom, Cisco Webex, Quiziz, Edmodo, Eduboy, dan Youtube.

Respons siswa dan guru terhadap distance learning tampak beragam. Secara umum, guru sudah merespons dengan baik terhadap distance learning. Hal tersebut terlihat dari hampir seluruh guru telah melaksanakan pembelajaran jarak jauh, sedangkan siswa cenderung masih terasa berat, mudah jenuh dan relatif merasa kurang menyenangkan dalam pembelajaran daring. Respons siswa pada 
jenjang pendidikan dasar dan menengah disinyalir lebih menyukai belajar secara langsung (tatap muka).

Dalam distance learning ditemukan berbagai kendala atau hambatan pada siswa. Faktor penghambat dimaksud di antaranya siswa tidak memiliki laptop atau ponsel pintar, tidak memiliki jaringan internet yang baik, siswa tidak memahami penggunaan media pembelajaran yang digunakan guru, dan lain-lain. Selain itu, faktor pendukung distance learning antara lain pemerintah, guru, dan fasilitas pembelajaran itu sendiri. Misalnya faktor teknologi, pemberian kuota gratis, perluasan akses internet, penyediaan fasilitas belajar seperti Rumah Belajar dan Belajar dari Rumah di TVRI.

\section{REFERENSI}

Abidin, Z., Hudaya, A., \& Anjani, D. (2020). Efektivitas Pembelajaran Jarak Jauh Pada Masa Pandemi Covid-19. Research and Development Journal of Education, 1(1), 131. https://doi.org/10.30998/rdje.v1i1.7659

Ahmad, I. F. (2020). Alternative Assessment in Distance Learning in Emergencies Spread of Coronavirus Disease (COVID-19) in Indonesia. Jurnal Pedagogik, 7(1), 195-222. https://ejournal.unuja.ac.id/index.php/pedagogik

Alifarose Syahda Zahra1, S. W. (2020). EFEKTIVITAS PEMBELAJARAN BASIS ONLINE DI IAIN TULUNGAGUNG DENGAN ADANYA KEBIJAKAN PHYSICAL DISTANCING ERA PANDEMI COVID 1. GERAM (GERAKAN AKTIF MENULIS), 8(1), 1-9. http://mpoc.org.my/malaysian-palm-oil-industry/

Andrianto Pangondian, R., Insap Santosa, P., \& Nugroho, E. (2019). Faktor - Faktor Yang Mempengaruhi Kesuksesan Pembelajaran Daring Dalam Revolusi Industri 4.0. Sainteks 2019, 56-60. https://seminar-id.com/semnassainteks2019.html

Anugrahana, A. (2020). Hambatan, Solusi dan Harapan: Pembelajaran Daring Selama Masa Pandemi Covid-19 Oleh Guru Sekolah Dasar. Scholaria: Jurnal Pendidikan Dan Kebudayaan, 10(3), 282-289. https://doi.org/10.24246/j.js.2020.v10.i3.p282-289

Arifin Nursyah Haris (2020). Respon Siswa Terhadap Pemeblajarandalam Jaringan Masa Pandemi Covid-19 di Madrasah Aliyah Al Amin Tabanan Denpasar.http://doi.org/10.38048/Jipjcb.v712.108

Arikunto, Suharsimi (2014). Dasar-dasar Evaluasi Pendidikan. Jakarta: Bumi Aksara 
Arizona, K., Abidin, Z., \& Rumansyah, R. (2020). Pembelajaran Online Berbasis Proyek Salah Satu Solusi Kegiatan Belajar Mengajar Di Tengah Pandemi Covid-19. Jurnal Ilmiah Profesi Pendidikan, 5(1), 64-70. https://doi.org/10.29303/jipp.v5i1.111

Arsyad, Azhar. 2014. Media Pembelajaran. Depok: PT Rajgrafindo Persada.

Artmanda Frista (2012). Kamus Lengkap Bahasa Indonesia. Jombang: Penerbit Lintas Media.

Azzahra, N. F. (2020). Mengkaji Hambatan Pembelajaran Jarak Jauh di Indonesia di Masa Pandemi Covid-19. Center for Indonesians Policy Studies, 19(2), 1-9.

Dimyati dan Mudjiono. 2013. Belajar dan Pembelajaran. Jakarta: Rineka Cipta.

DIRJEN PENDIDIKAN ISLAM DEPAG RI. (2006). Undang-undang dan Peraturan Pemerintah RI tentang Pendidikan. Jakarta: Depag RI

Elisvi, J., Archanita, R., Wanto, D., \& Warsah, I. (2020). Analisis Pemanfaatan Media Pembelajaran Online Di Smk It Rabbi Radhiyya Masa Pandemi Covid19. Al-Tarbawi Al-Haditsah: Jurnal Pendidikan Islam, 5(2), 16-42. https://doi.org/10.24235/tarbawi.v5i2.6721

Fauzi, Ahmad. 2014. Manajemen Media Pembelajaran. Cirebon: Eduvision Publishing.

Fikri, dkk., (2021). Kendala dalam Pembelajaran Jarak Jauh da Masa Pandemi Covid-19:

Sebuah Kajian Kritis. Jurnal Educatio And Development. DOI https://doi.org/10.37081/ed.v911.2290

Hanifah Salsabila, U., Irna Sari, L., Haibati Lathif, K., Puji Lestari, A., \& Ayuning, A. (2020). Peran Teknologi Dalam Pembelajaran Di Masa Pandemi Covid-19. Al-Mutharahah: Jurnal Penelitian Dan Kajian Sosial Keagamaan, 17(2), 188198. https://doi.org/10.46781/al-mutharahah.v17i2.138

Karim, B. A. (2020). Pendidikan Perguruan Tinggi Era 4.0 Dalam Pandemi Covid-19 (Refleksi Sosiologis). Education and Learning Journal, 1(2), 102. https://doi.org/10.33096/eljour.v1i2.54

Kisworo, T. W., \& Sumarni, W. (2020). Analisis Pelaksanaan Pembelajaran Jarak Jauh Dalam Masa Pandemi. SEMINAR NASIONAL PASCASARJANA 2020: ISSN: 2686 6404, 21(1), 1-9. https://proceeding.unnes.ac.id

Lestari, A. S., \& Gunawan. (2020). The Impact of Covid-19 Pandemic on Learning Implementation of Primary and Secondary School Levels. 1(2), 58-63. https://journal.publication-center.com/index.php/ijece/article/view/141

Lestari, W. (2021). Pemanfaatan Whatsapp Sebagai Media Pembelajaran Dalam Jaringan Masa Pandemi Covid-19 Di Kelas VI Sekolah Dasar. Journal of 
Chemical Information and Modeling, 53(9), 1689-1699.

LPMP DKI Jakarta (2020), Pendapat Siswa tentang Pembelajaran Jarak Jauh Secara Online. http://lpmpdki.kemdikbud.go.id

Naserly, M. K. (2020). Implementasi Zoom, Google Classroom, Dan Whatsapp Group Dalam Mendukung Pembelajaran Daring (Online) Pada Mata Kuliah Bahasa Inggris Lanjut. Journal of Chemical Information and Modeling, 4(2), $155-165$.

dikpora.jogjaprov.go.id/index.php/jurnalideguru/article/view/129 https://jurnal-

Nugroho, Elfan Fajar. (2020, 8 Agustus). "KPAI Tak setuju dengan Kebijakan

Kemendikbud yang Izinkan Sekolah tatap Muka: Siapa yang Menjamin?". Tribun Wow.Com. [online], halaman tersedia: https://wow.tribunnews.com/amp/2020/08/08/kpai-tak-setuju-dengankebijakan-kemendikbud-yang-izinkan-sekolah-tatap-muka-siapa-yangmenjamin?page $=2 \& \_g a=2.135617461 .545628516 .1618819883$ 2002055575.1600555267. [19 April 2020].

Padli, F., \& Rusdi. (2020). Respon Siswa dalam Pembelajaran Online Selama Pandemi. Social Landscape Journal, 1(3), 1-7.

Pusat Pendidikan dan Pelatihan Pegawai. (2020, 24 Maret). "Surat Edaran Mendikbud No 4 Tahun 2020 Tentang Pelaksanaan Kebijakaan Pendidikan dalam Masa Darurat Penyebaran Corona Virus Disease (Covid-19. )". [online]. Halaman Tersedia: https://pusdiklat.kemdikbud.go.id/surat-edaran-mendikbudno-4-tahun-2020-tentang-pelaksanaan-kebijakan-pendidikan-dalam-masadarurat-penyebaran-corona-virus-disease-covid-1-9/. [19 April 2021]

Roni Hamdani, A., \& Priatna, A. (2020). Efektifitas Implementasi Pembelajaran Daring (Full Online) Dimasa Pandemi Covid- 19 Pada Jenjang Sekolah Dasar Di Kabupaten Subang. Didaktik: Jurnal Ilmiah PGSD STKIP Subang, 6(1), 19. https://doi.org/10.36989/didaktik.v6i1.120

Simanjuntak, S. Y., \& Kismartini. (2020). Respon Pendidikan Dasar Terhadap Kebijakan Pembelajaran Jarak Jauh Selama Pandemi Covid-19 di Jawa Tengah. Jurnal Ilmiah Wahana Pendidikan, 6(3), 308-316. https://doi.org/10.5281/zenodo.3960169

Sri Yunita, dkk. (2020) Respon Guru Terhadap Kebijakan Pembelajaran Jarak Jauh Selama Pandemi Covid-19. Jurnal Ilmiah Pendidikan Citra Bakti https://doi.org/10.38048/jipcb.v7i2.108.

Sudarmoyo. (2020). Podcast sebagai Media Pembelajaran Jarak Jauh. 5(May), 811 .

Sudjana, Nana. (2013). Pembinaan dan Pengembangan Kurikulum di Sekolah. 
Bandung: Sinar Baru Algensindo.

Sudjana, Nana dan Ahmad Rivai, (2013), Media Pengajaran, Bandung: Sinar Baru Algesindo.

Sutia, C., \& Sagita, S. (2020). Tanggapan Siswa , Orang Tua dan Guru terhadap Pembelajaran Jarak Jauh Selama Pandemi Covid-19 Students, Parents and Teachers ' Responses to Distance Learning During The Covid-19 Pandemic. Jurnal Inspirasi, 19(2), 156-165.

Suyanto dan Jihad Hisyam (2010). Refleksi dan Reformasi Pendidikan di Indonesia

Memasuki Milenium III, Yogyakarta:Penerbit Adi Cita Karya Nusa)

Syaiful Bahri Djamarah \& Aswan Zain (2014). Startegi Belajar Mengajar. Jakarta:

Penerbit Rineka Cipta

Unger, S., \& Meiran, W. (2020). Student Attitudes Towards Online Education during the COVID-19 Viral Outbreak of 2020: Distance Learning in a Time of Social Distance. International Journal of Technology in Education and Science, 4(4), 256-266. https://doi.org/10.46328/ijtes.v4i4.107 